\title{
Objectives and Indexes for Implementation of Sponge Cities-A Case Study of Changzhou City, China
}

\author{
Zhengzhao Li ${ }^{1}$, Mingjing Dong ${ }^{2,3}$, Tony Wong ${ }^{4}$, Jianbin Wang ${ }^{4}$, \\ Alagarasan Jagadeesh Kumar ${ }^{2,3}$ and Rajendra Prasad Singh 2,3,* \\ 1 Changzhou City Planning and Design Institute, Changzhou 213003, China; lzzcool@sohu.com \\ 2 School of Civil Engineering, Southeast University, Nanjing 210096, China; 220151121@seu.edu.cn (M.D.); \\ jaga.jagadeesh1987@gmail.com (A.J.K.) \\ 3 Southeast University-Monash University Joint Research Centre for Water Sensitive Cities, \\ Nanjing 210096, China \\ 4 CRC for Water Sensitive Cities, Clayton, VIC 3800, Australia; tony.wong@crcwsc.org.au (T.W.); \\ wang.jianbin@crcwsc.org.au (J.W.) \\ * Correspondence: rajupsc@seu.edu.cn; Tel.: +86-25-83993223
}

Received: 12 January 2018; Accepted: 19 March 2018; Published: 10 May 2018

\begin{abstract}
This paper presents a framework of objectives and indexes for sponge cities implementation in China. The proposed objectives and indexes aims to reflect whether the city is in accord with the sponge city. Different cities have different objectives and indexes as each city has its own geologic and hydrogeological conditions. Therefore, the main problems (e.g., water security and flood risks) in the central urban area of Changzhou city, China were evaluated scientifically. According to the local conditions, four objectives and eleven indexes have been made as a standard to estimate the sponge city and set a goal for the city development to reach the goal of sustainable urban development. The strategy of process control was implemented to improve the standard of urban drainage and flood control facilities, regulate total runoff and reduce storm peak flow, and the ecological monitoring of the function of the rivers and lakes. The objectives of sponge cities include water security, water quality improvement, healthy water ecosystems, and water utilization efficiency. Urban flood prevention capacity, river and lake water quality compliance, and annual runoff control are the key objectives to encourage the use of non-conventional water resources.
\end{abstract}

Keywords: Yangtze river delta; sponge cities; water ecology; water resources; urban flood risk

\section{Introduction}

Rapid economic development and urbanization in many developed and developing countries have created numerous environmental as well as developmental challenges. For example, in China more than 600 cities are exposed to frequent flooding, which has a huge social, economic and environmental impact. As waterlogging is considered as one of the major underlying causes of these impacts, the management of urban drainage is a big challenge for both researchers and government authorities [1,2]. Globally, flooding is one of the most common and destructive natural perils causing an average USD 200 billion annually in damages [3]. Most densely populated areas are in coastal zones and in river catchments prone to flooding. Sea-level rise, economic development, and increased frequencies and intensities of storms will require that we continuously have to invest in adapting our flood risk management (FRM) systems, including flood protection infrastructure such as levees, dams and urban drainage systems [3-7]. Water pollution in developed coastal regions due to the higher industrialization and rapid urbanization has become a very critical environmental issue and require proper scientific and effective measures to solve this problem [8]. Dealing with this crisis 
calls for a multi-stakeholder approach (involving governments, local councils, and citizens). Urban drainage and urban water cycle management have seen a significant change in recent decades leading to an integrative approach to reduce flooding in which multiple objectives in the design and decision making process have been incorporated [9-12].

Various integrated sustainable urban development practices have been developed and adopted in recent years. Many researchers are engaged in research and development of sustainable urban water management approaches such as the concept of sponge cities in China [10-16]. A sponge city refers to sustainable urban development including flood control, water conservation, water quality improvement and natural ecosystem protection. It envisions a city with a water system which operates like a sponge to absorb, store, infiltrate and purify rainwater and releases it for reuse when needed [8]. The sponge city program, launched by the Chinese government in 2014, takes inspiration from the low impact development (LID), best management practices (BMPs) and best planning practices (BPPs) and green infrastructure (GI) in the US [17,18] and Canada $[19,20]$ sustainable drainage systems or sustainable urban drainage systems (Sus Drain/SUDSs) and integrated urban water management (IUWM) in the UK [21,22], alternative techniques (ATs) in France [23] and other European countries [24] and water sensitive urban design (WSUD) in Australia [25] and New Zealand [26]. It promotes natural and semi-natural measures in managing urban storm water and wastewater as well as other water cycles. Since the launch of the program, China has been implementing the sponge city construction initiative, which represents an enormous and unprecedented effort to achieving urban sustainability. A total of 16 cities have been nominated in the first batch as model sponge cities in 2015 and 14 model sponge cities have been nominated in 2016 and received financial aid from the central government of China (Figure 1). According to preliminary estimations, the total investment on the Sponge city construction (SCC) will be roughly 100 to 150 million Yuan (RMB) (US \$15 to US \$22.5 million) average per square kilometer or 10 Trillion Yuan (RMB) (US \$1.5 Trillion) for the 657 cities nationwide.

(a)

(b)
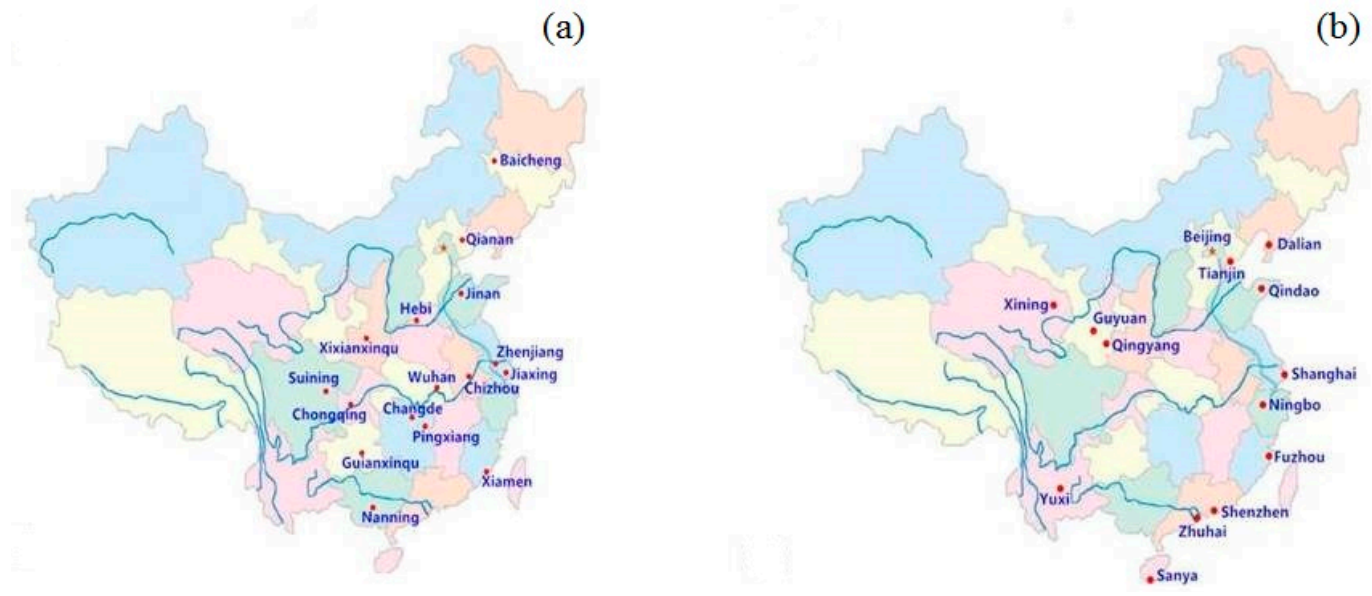

Figure 1. The Geographical distribution of model sponge cities in china; (a) Phase 1, (b) Phase 2.

To achieve a sustainable urban water ecosystem, it is important to align the interventions related to sponge facilities (referred to as technologies required to develop/transform a city into a Sponge City), ecological treatment of polluted water, non-point source pollution reduce, and rainwater utilization. This alignment should be based on an assessment of the effectiveness of these interventions and their interactions. For example, to reducing the urban heat island effect and improving the ecological environment, an understanding is needed of the relationship between sponge facilities, improvement of micro-climate, and biodiversity. In this paper we are presenting a rational approach to conducting a rapid assessment to improve the livability and sustainability of cities. This approach consists of a framework of objectives and an index system for a sponge city [27-30]. Index is the term generally used for scientific indicators. Based on the regional characteristics of Changzhou city, 
objectives and indexes related to the current situation have been identified and classified in order to scientifically define and guide the future direction towards new urban developments which comply with the Sponge City Concept (SCC). Paying heed to local conditions is the best way to promote SCC, using an evaluation function, prediction function and guiding function of the objectives and index system. To evaluate whether the objectives can be met and to index them scientifically, based on an objective-oriented approach, relevant urban policy documents, planning, and public demands need to be analyzed to understand the scientific basis and internal driving power to achieve established and periodical objectives and indexes. As well, it would be of great significance to construct sponge cities where stormwater can be naturally stored, purified, and reused [31]. Therefore, the overall objectives and indexes for construction of future sponge cities have been evaluated in the current work. These objectives include, water security, water quality improvement, water discharge management, healthy water ecosystem, water use efficiency, urban flood control capacity, river and lake water quality compliance rate, and the rate of annual runoff control. These are the key objectives to encourage the use of non-conventional water resources [32]. This paper shows that the proposed objectives and index system can provide a guideline for sponge city construction and urban design and planning for future cities. It can also provide a standard to estimate the effects of sponge city construction and set goals for government departments for urban planning, design and construction. Moreover, it is an effective means to ensure that the related sponge facilities can be implemented in the process of urban planning construction.

\section{The Sponge City Concept}

The concept of "Sponge city" emphasizes the use of natural resources such as soil and vegetation as part of the urban runoff control strategy, which is similar to the low impact development (LID) and green infrastructure (GI) practices being promoted in many parts of the world. The sponge city construction goals not only affect urban flood control but also rainwater harvesting, water quality improvement, natural water discharge and ecological restoration [27]. The primary goals for SCC in China includes on-site retention of $70-90 \%$ of average annual rainwater by applying the GI concept and using LID measures, preventing urban flooding, improving urban water quality, mitigating impacts on natural ecosystems, and alleviating the urban heat island impacts (UHI) [28]. Particularly in the Yangtze river delta most of the cities are facing urban flooding problems and runoff pollution is also increasingly affecting the water quality of urban water bodies. Therefore, implementation of sponge cities in this delta is very imminent and as it aims to reduce flood risk and enhances the urban water ecology. The Sponge city construction will also create investment opportunities, infrastructure upgrading, engineering products and new green technology [29].

In the Yangtze river delta, local governments such as the provincial and city governments have to implement the sponge city construction in new development areas. The water system of these areas consists of a dense river network with a slow flow rate of the rivers [8,14]. These newly developed urban areas are receiving irregular precipitation, and have a weak water environmental buffering capacity and thus comprise a vulnerable ecosystem. Therefore, it is critical to have an understanding of the impact of sponge city construction on the hydrological and ecological processes which are as part of the river network. For collection and storage of rainwater effectively and for full rain water utilization, it is imperative to properly understand interventions to establish a sponge city (functions of rain stagnation, purification, infiltration, slow release, and transfusion, such as bio-retention cell, artificial wetland, permeable pavement, existing drainage facilities and the network of rivers and lakes. It can also help to effectively improve the water quality and to make the water cycle in the city more sustainable. 


\section{Materials and Methods}

\subsection{Study Area}

Changzhou city is located on the south bank of the Yangtze river which is a typical delta region in the eastern coastal area of China with plentiful water resources (Figure 2). This region lies at the heart of China and is also a globally prominent economic sector. There is a dense network of waterways, such as canals and rivers in this region. Most of the cities in this region have a subtropical monsoon climate with high rainfall in summer which often results in severe urban flooding problems $[17,28,30]$. According to the present status and characteristics of the ecological environment, urban lake and river systems, drainage facilities, land use types etc., Changzhou city is facing two outstanding problems of urban flooding and poor quality of the water environment.

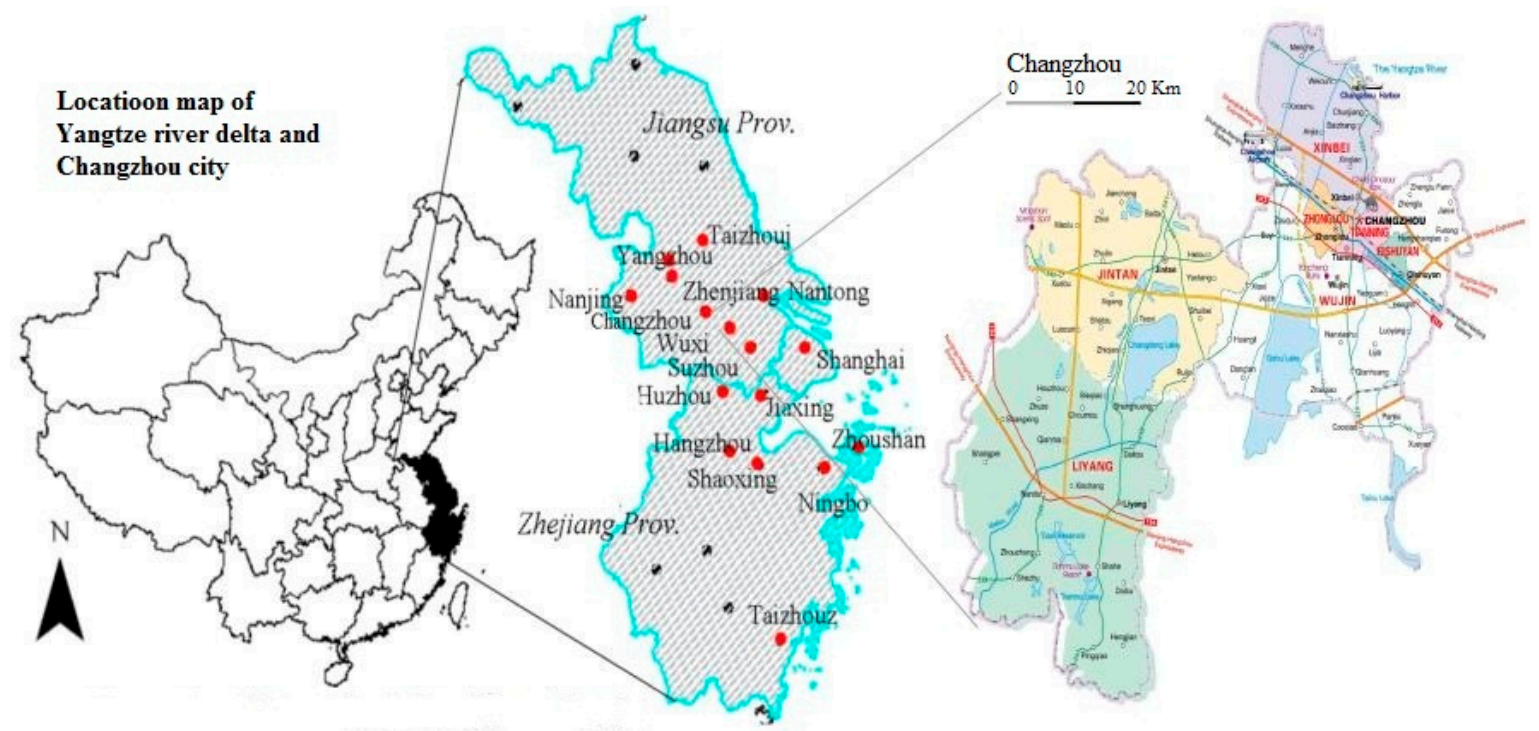

Figure 2. Geographical location of Changzhou city in the Yangtze river delta region, China.

\subsection{Technological Pathways for Construction of Sponge Cities}

The sponge city concept is based on four target categories: (1) water security, (2) water environment, (3) water ecology, and (4) water resources, to improve urban livability and sustainability comprehensively and determine the framework of objectives and indexes [11]. According to the national development plan for achieving the sustainable urban development goal in China, there are 15 target objectives and indexes for construction/implementation of sponge cities [11]. Based on an problem-oriented to analyze existing problems, background advantage and confronted difficulties and an objective-oriented approach to analyze relevant policy documents, relevant planning, and public demands, overall objectives, building index and control index on the spatial scale of a unit (district) were made for the construction of sponge city by scientifically evaluating their feasibility according to existing advantage and internal driving power to achieve established and periodical objectives and indexes. These objectives and indexes will be assessed separately as qualitatively or quantitatively based on existing problems and challenges, background advantages, relevant policies and public views to achieve the target standards provided in the master plan, regulatory detailed plan and control detailed plan. Background advantages are generally referred to local advantage of building the sponge city, such as rich ecological resources, good natural conditions and favorable hydrological conditions etc. Changzhou city will serve as a case study for the sponge city evaluation process. The technological pathways of objectives and indexes for construction of sponge facilities in Changzhou city are presented in Figure 3. 


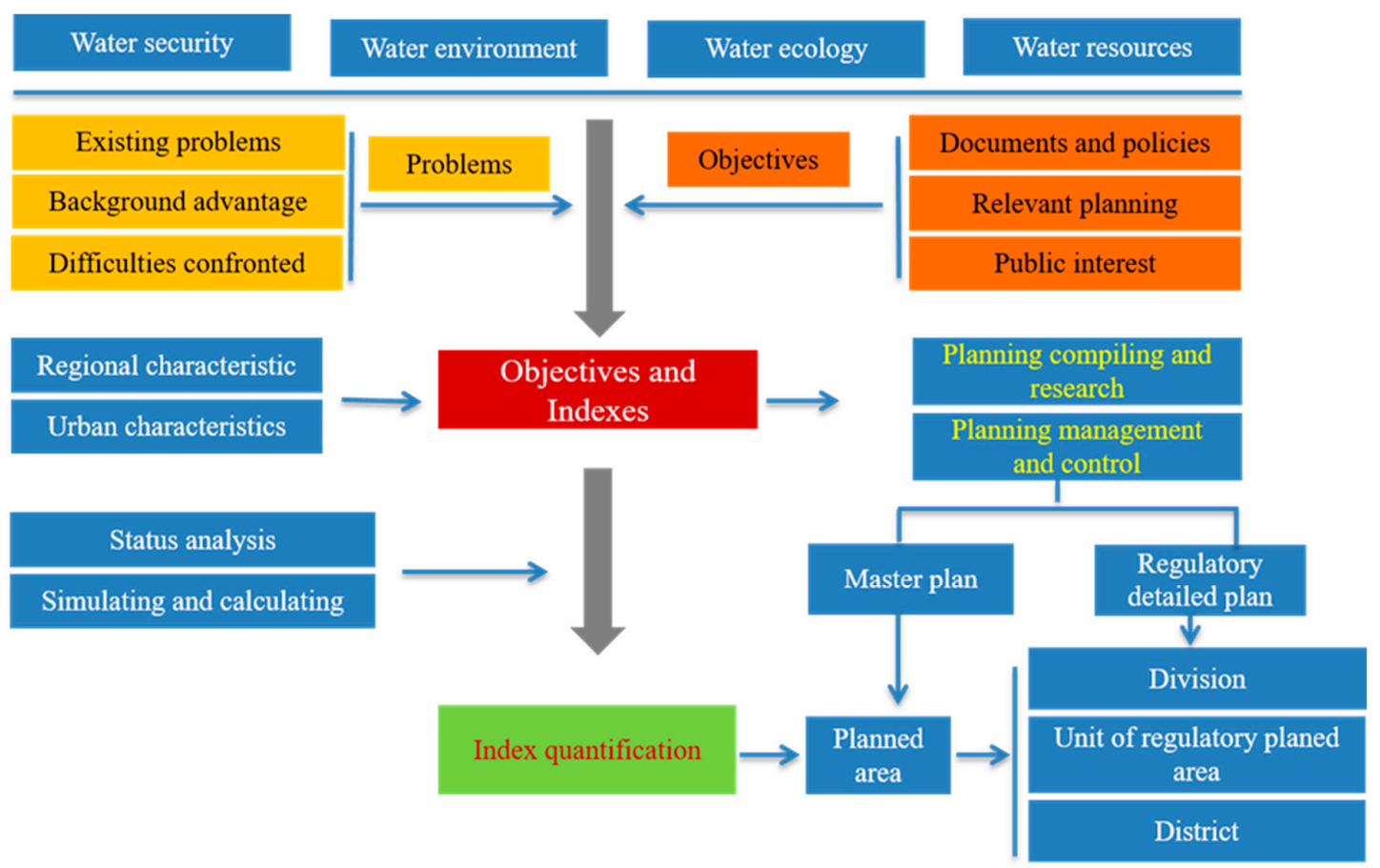

Figure 3. Technological pathways of objectives and indexes for the construction of a sponge city.

The different objectives and indexes will be classified as constraining or enabling local conditions/factors. Based on the knowledge about the local conditions and requirement of the sponge city, we have to determine the objectives and indexes which are in accord with the local problems of water security, water environment, water ecology and water resources. The best way to promote sponge city construction is to develop and implement the construction of sponge cities in local conditions on different areas [33]. The overall objectives of sponge cities are to encourage the use of non-conventional water resources including water security, water environment quality improvement, water ecosystem health, water use efficiency, urban flood control capacity, river and lake water quality compliance rate, and annual runoff control $[25,26,33]$. The specific site indicators and detailed objectives for sponge cities are quantified by determining and implementing building indexes vis-a-vis overall objectives. The urban water runoff peak flow could be effectively reduced by fences and, green coverage and bioretention systems. Urban runoff quality could also be effectively increased by implementation of bioretention systems [33]. Factors such as, the degree of slopes alongside the river and lake ecosystems, runoff quality, groundwater table, and the permeable paving in urban areas were included as key parameters in the current work. The specific objectives of the development of sponge city in Changzhou city were to achieve water security assurance, water quality improvement, healthy aquatic ecosystems and effective utilization of water resources. The realization of these objectives are rest with indexes to further refine and quantify them. The relationship between objective and index is both mutually independent and unified. Framework objectives and indexes for sponge cities are presented in Figure 4. 


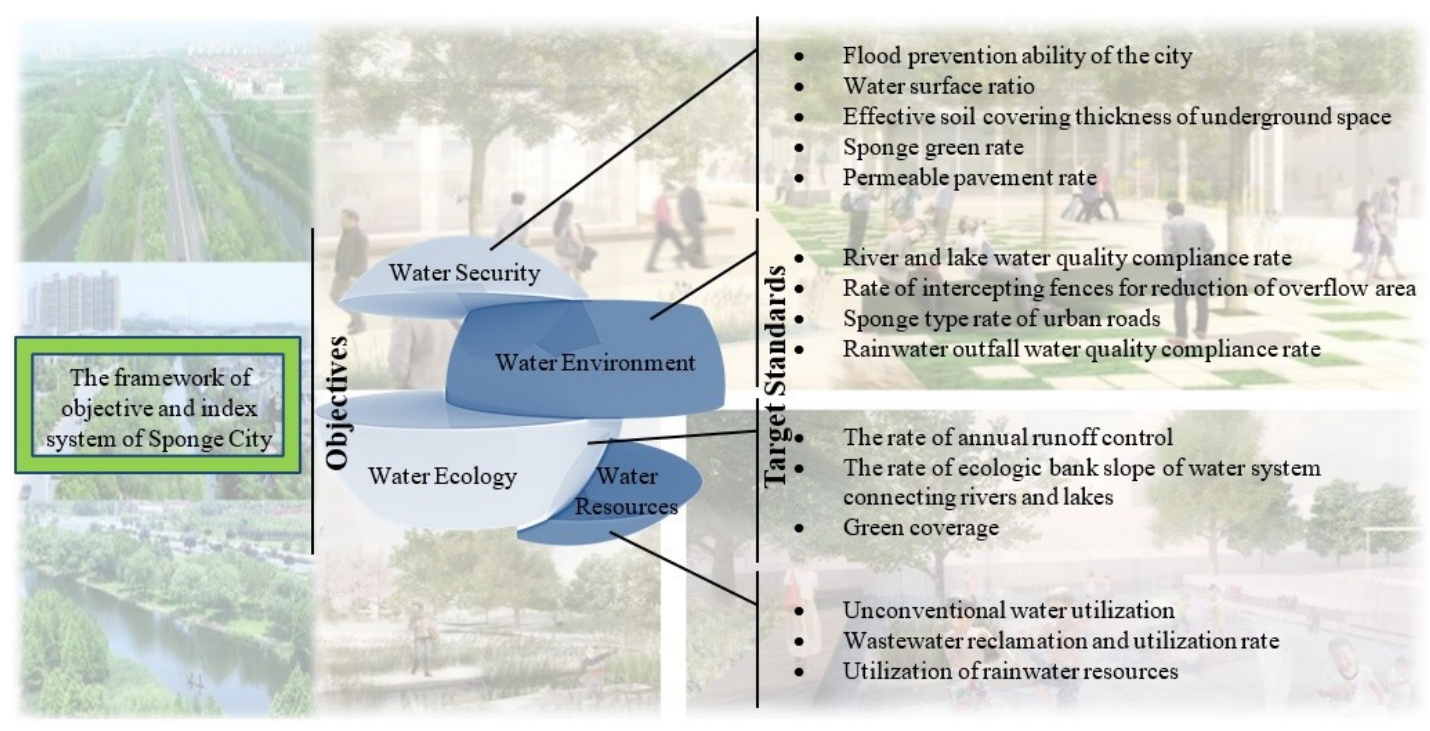

Figure 4. The framework of objectives and index systems for sponge cities.

\section{Results and Discussion}

Current study has been divided into four categories viz. water security, water environment, water ecology, and water resources based on the existing key problems (e.g., water security and flood risks) occurred in the central urban area of Changzhou city, China. Furthermore, four objectives and eleven indexes have been made as a standard to estimate the sponge city and set a goal for the city development to reach the goal of sustainable urban development.

\subsection{Water Security}

The main problem of water security in Changzhou city is due to the low water to land surface ratio and the length of the river network. The high amount of hard surface areas is a serious challenge, and the lowland area was existed for a long time and the frequency of heavy precipitation events has increased. Therefore, water security issues and the risk of flooding and its ensuing problems are increasing and have been evaluated scientifically in the central urban area of Changzhou city to find out the most effective strategy to solve these problems (Figure 5).

The strategy involves the improvement of the standard for urban drainage and flood protection facilities, regulation of total runoff and reduce storm flood peak, and the ecological regulation function of rivers and lakes [34,35]. Based on existing urban drainage facilities, we have also considered in the strategy to make full use of an urban green system which has the function of rainwater retention with the use of permeable materials to let rainfall locally infiltrate. Therefore, the objective of the this study was to develop indexes which include water surface ratio, effective soil covering thickness of underground space, sponge green rate, permeable pavement rate, intercepting fence, bioretention to enhance the city's ability to prevent the flooding problem $[18,25,26,35]$.

\subsubsection{The City Flood Prevention Ability}

The frequency of urban water disasters caused by heavy rain or continuous rainfall can be reduced to lower design rainfall return periods by improving the capacity of inadequate urban drainage facilities [36]. Flooding associated with return period exceeds the storm sewer capacity which is different from what is needed for drainage water; this puts emphasis on utilizing a variety of measures to cope with rainstorm of a great return period. Flood return period and storm sewer capacity should to be comply with the drainage facilities [37]. By accounting for the urban water system, drainage pipe network, runoff control, low impact development construction and other measures, sponge city 
construction is the best way to reduce frequency of flood disaster. Changzhou city has an area with a dense water network, low-lying terrain and poor connectivity of water networks. The water-surface ratio in the center of the city is $4.4 \%$. The pressure in terms of peak volumes of storm water entering the existing drainage infrastructure is very high and results in a higher risk of system failure than before. Therefore, the primary task of urban water safety is to improve the capacity of the drainage system in order to reduce the risk of flooding. According to the present situation of the central city in Changzhou, the existing standards of flood control and flooding are very low [38].

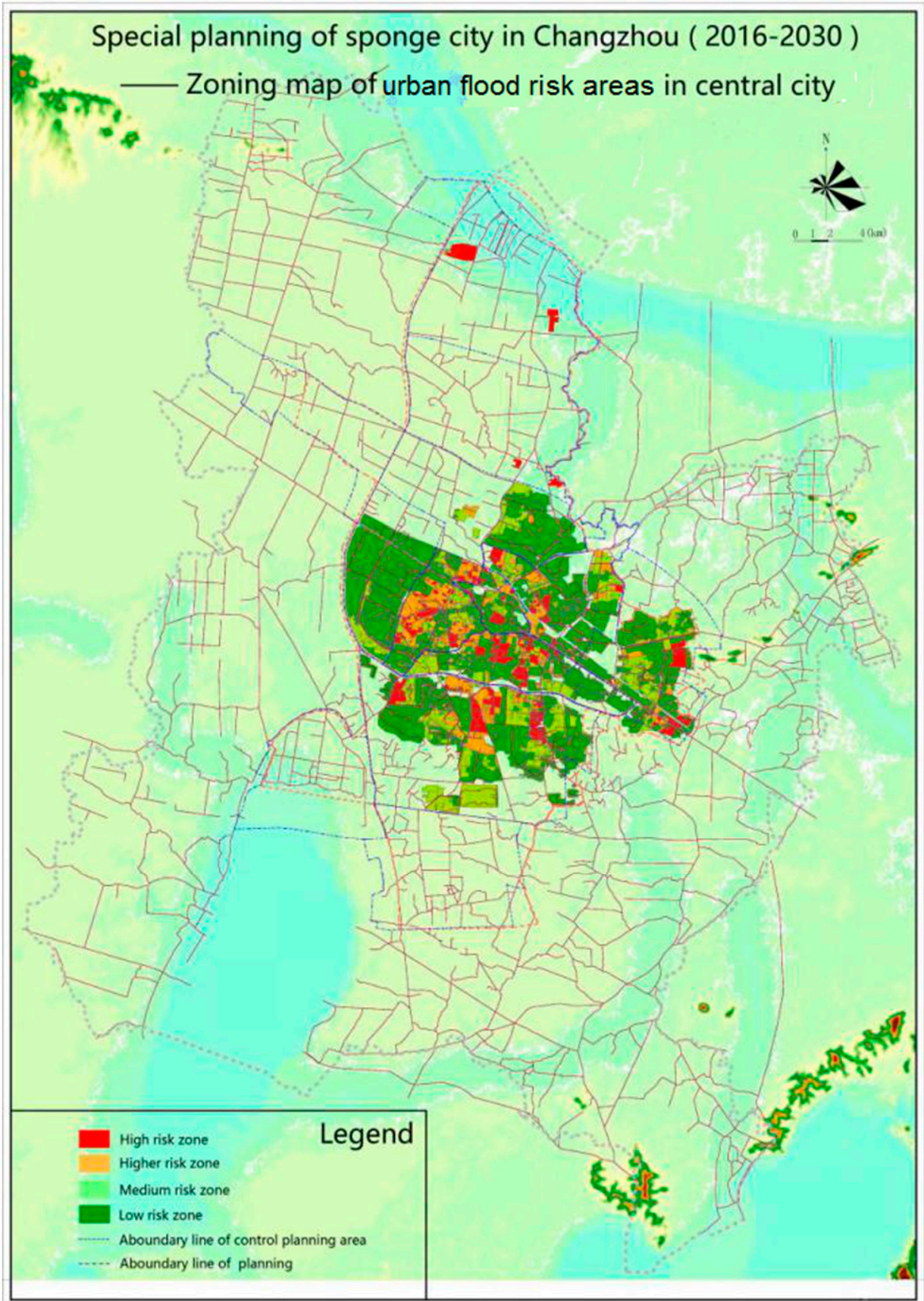

Figure 5. Map displaying the flood risk spots in the central urban area in Changzhou. 


\subsubsection{Effective Soil Covering Thickness for Underground Spaces}

Effective soil covering thickness of underground space is refer to the distance between the top of facilities of underground space and the datum grade of ground. The available "distance" affects the feasibility of building sponge facilities. Often enough room can be designed to construct sponge city practices such as permeable pavement or shallow bioretention.

\subsubsection{Sponge Green Factor}

Sponge green factor refers to the percentage of total green space area which has the ability to store, convey and treat the surface runoff. Green space vegetation has the functions of water purification and the provision of other eco-system services. Green sponge facilities which have effects on hydrology and water quality by reducing non-point source pollution load, thus improving the quality of rivers and lakes. The type of the land-use planning unit is not used correctly, and therefore, this indicator needs to be delineated according to the planning unit.

\subsection{Water Environment}

The main problems of water environment in Changzhou city are as follows: high pollution load discharged from sewage treatment plants, high volumes of combined sewage overflow (CSOs), heavy non-point source pollution in runoff and inadequate facilities for the monitoring and thus managing hydrology and water quality based on the water environment and the characteristics of the Yangtze River delta region. The objective and indexes for improving the water quality in the central city of Changzhou have been evaluated and presented in Sections 4.2.1 and 4.2.2.

\subsubsection{The Reduction of CSO}

Combined sewer outflow is a condition where sometimes, combined sewers receive higher than normal flows during heavy rainfall and sewage treatment plants are unable to handle flows that are more than the designed capacity [38]. Due to this, a mix of excess storm water and untreated wastewater discharges directly into the city's waterways at certain outfalls [38]. According to "Urban Drainage Plan in Changzhou (2011-2020)" [29], the daily average river discharge in 2010 was $72,000 \mathrm{~m}^{3} /$ day, but the actual average river discharge in 2015 increased to $140,200 \mathrm{~m}^{3} /$ day, a $14 \%$ annual increase from 2010 to 2015. If the annual rate of increase will gradually drop, the average rate could become $8 \%$ in $2015-2020$ and even as low as $4 \%$ in $2021-2030$.

\subsubsection{Sponge City Road Rate}

Sponge city road rate refers to the proportion of the area of the road which is used in sponge facility to control the runoff. The total area of the present roads and the squares in built-up areas of the central city is about $48.9 \mathrm{~km}^{2}$ and the occupancy rate is about $12.7 \%$. The total area of planned roads and squares in built-up area of the central city is $139.8 \mathrm{~km}^{2}$, with occupancy rate of about $28.5 \%$. The road system collects and transports runoff, and it is also one of the main sources of urban non-point source pollution. Newly built roads have to fully comply with the sponge principles, and improvements to the existing roads will promote implementation of more sponge-type roads in the near future [39].

\subsection{Water Ecology}

Because ecological protection was neglected in the early stage of urbanization in Changzhou city, some ecosystems have been damaged; while others, such as wetlands, lakes, and urban green areas are continuously shrinking. The deterioration of the ecological function of these systems have become an important factor that restricts sustainable development. As the main issues are related to water ecology, the objectives and indexes have been determined to improve the health of water ecosystems in the central area of Changzhou city. These include: (1) annual runoff control, and (2) the indexes of the river and lake ecological slope rate and green coverage [40]. 


\subsubsection{The Annual Runoff Control Rate}

The annual runoff control rate is defined as the proportion of the rainfall which is controlled (not discharged) from the total rainfall in a year. It was analyzed and calculated according to statistical analysis of yearly data related to the natural and artificial enhanced way of penetration, storage, evaporation (transpiration), etc. [41]. According to the relationship between the annual runoff control rate, designed rainfall and rainfall frequency, the rainfall characteristics of Changzhou city and the rainfall data of the past 30 years were analyzed to determine the value of annual runoff control rate [42]. The relationship between the annual runoff control rate and the design rainfall is illustrated in Table 1 and Figure 6.

Table 1. Comparison of annual runoff control rate, the design rainfall and rainfall frequency in Changzhou city.

\begin{tabular}{ccccccccc}
\hline Annual Runoff Control Rate (\%) & $\mathbf{5 0}$ & $\mathbf{6 0}$ & $\mathbf{6 5}$ & $\mathbf{7 0}$ & $\mathbf{7 5}$ & $\mathbf{8 0}$ & $\mathbf{8 5}$ & $\mathbf{9 0}$ \\
\hline Design rainfall (mm) & 10.1 & 14 & 16.5 & 19.5 & 23.2 & 28.2 & 35.2 & 45.7 \\
Rainfall frequency (\%) & 72.9 & 80.0 & 83.3 & 86.4 & 89.5 & 92.0 & 94.6 & 96.4 \\
\hline
\end{tabular}

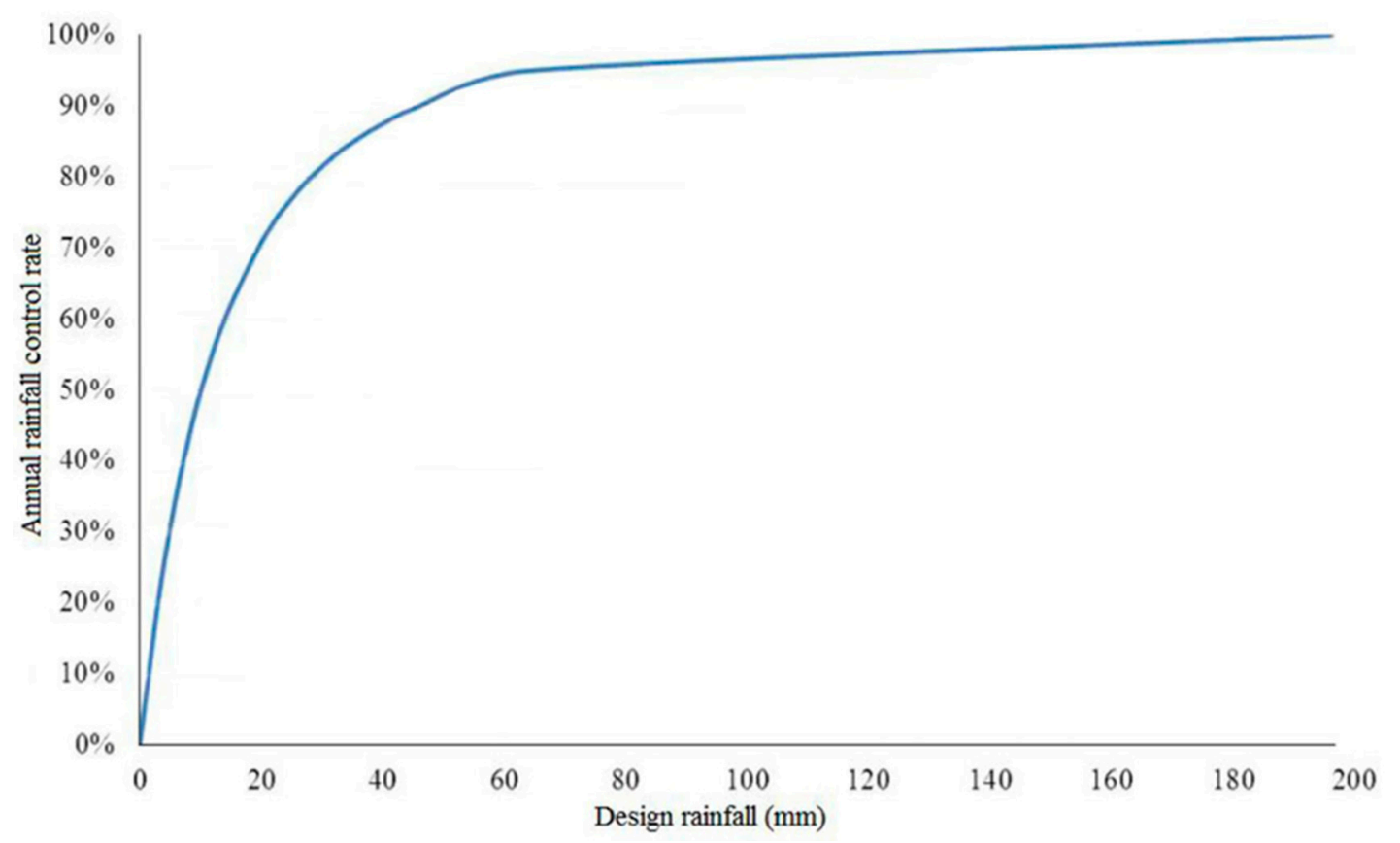

Figure 6. Corresponding relationship between the annual runoff control rate and the design rainfall.

\subsubsection{The River and Lake Ecological Revetment Rate}

The total length of the ecological revetments rate (excluding shipping river bank and the mean flood discharge channel) analyzed according to the "action plan for construction of sponge city in Changzhou city" $[17,29]$, which reveals that the construction of ecological revetment ratio for sponge city required that, by 2016, must exceed $75 \%$ in the central city. Whereas, the "Index system of water ecological civilization in Jiangsu" required that the ratio of ecological revetment must exceed 70\%. Changzhou city, with a dense river network has a higher proportion of hard riverbanks and lakes. The rigidity of the revetment obstructs material exchanges between soil and water, which can destroy the ecological function of the natural embankment and reduce the capacity of water self-purification. These factors may lead to water quality deterioration. Therefore, the recovery of ecological function of river banks and lake shores is one of the effective water quality improvement measures [42]. 


\subsubsection{Green Coverage Ratio}

The green coverage ratio is the vertical projection of plants/shrubs to the total area. In the "overall planning of Changzhou city" (2015), the green coverage ratio was $39 \%$, increase to $43 \%$ in the central city. According to the "Sponge city construction action plan for Changzhou city", the green ratio in built-up areas will be $40 \%$ and green coverage rate is predicted to be $45 \%$ by 2020 . The green coverage ratio will gradually increase taking into account the natural growth of trees/plants. Therefore, the basis for improving the green ration is to increase the proportion of trees/plants, which can effectively alleviate the urban heat island effect [43].

\subsubsection{Sponge City Construction}

The flood control capacity of Changzhou city should be able to effectively carry the 24hrs storm events for the next $30 \mathrm{yrs}$, and by doing so, the storm water accumulated areas in central urban areas should be basically eliminated. By 2030, current central urban areas which are prone to storm flooding will no longer exist for the next 50yrs. The river drainage capacity should ensure that the storm events will not be overflowing in 20yrs. The black and odorous water bodies in Changzhou city should be basically revived by 2020 , and $85 \%$ of rivers and lakes in the central urban area should meet the water quality standards. By 2030,100\% of the rivers and lakes will meet the water quality standards. Annual runoff control ratio of sponge city overall objectives in Changzhou city are divided into control units and land-use types. Annual runoff control ratio will vary because the proportions of land types in control units are different; as such annual runoff control ratio should be calculated in control units [44]. Based on the overall planning for goals for Changzhou city, the unconventional water resource utilization rate in the central urban area should be more than $20 \%$ by 2020 , and should be more than $25 \%$ by 2030 .

\subsection{Water Resource}

There are abundant water resources in Changzhou city, and yet its water supply capacity almost completely depends on the Yangtze River. In addition, rainwater and sewage collection and treatment systems are insufficient. Therefore, the ecological function of an urban area as a watershed and water-supply area is difficult to fully utilize. The main problems of water security in Changzhou city are as follows: the large dependency on "conventional" water resources such as river and lakes, pollution-induced water shortages and limited utilization of "unconventional" water resources. Thus, the objectives and indexes were determined to enhance the water utilization rate in Changzhou city, which included the usage of unconventional water resource.

\subsubsection{The Rate of Unconventional Water Utilization}

The unconventional water utilization is the proportion of the water consumption which is not supplied by water treatment plants, and includes rainwater, sewage treatment plant effluent, gray water, and industrial enterprises that reuse water. Changzhou city initially had no water shortages but recently it has suffered from pollution-induced water shortages. The total water consumption in Changzhou city in 2015 was 45746.69 million $\mathrm{m}^{3}$ (not including the water consumption of thermal power industry), of which urban recycled water and rainwater utilization contributes 7665 and 3.6 million $\mathrm{m}^{3}$. Therefore, a major opportunity exists to increase the proportion of unconventional water (e.g., rain water and recycled water), to improve the quality of effluent from sewage treatment plants, and to augment the available quantity of unconventional water resources. These waste water treated through constructed wetlands and ecological treatment (reclaimed water); both can meet the demand for some municipal, industrial, agricultural and landscape irrigation. The ratio of reclaimed water, which meets or surpasses the Chinese standards for surface water class IV requirements, describes the total volume of wastewater discharged from sewage treatment plants. The present ecological processing capacity, sewage load and ecological treatment rate is 10.52 million tons, 69.57 million tons 
and $15.1 \%$, respectively. At present, the centralized sewage treatment annual growth rate is $17.5 \%$ in Changzhou city. It is estimated that the annual volume of sewage treatment will increase at a rate of $8 \%$ from 2015 to 2020 . The biological treatment rate of effluent from sewage treatment plants will reach to $22 \%$ by 2020 . It is estimated that the annual volume of sewage undergoing biological treatment will be $5 \%$ from 2015 to $2020[17,29]$.

\subsubsection{The Rainwater Resource Utilization Rate}

The rainwater resource utilization rate refers to the proportion of tap water substituted for rainwater resource of the total amount of tap water. It is the severe reality in Changzhou city that the water environment is poor, thus making water resources crisis more prominent. The abundant rainwater resources in Changzhou city are not efficiently used under the traditional approach of urban drainage systems. A vast majority of rainwater runoff is directly discharged into the rivers and lakes, increasing the burden on urban drainage infrastructure. Therefore, an increase of the volume of harvested rainwater provides an ecological function of urban water supply, lessening the need to supply high quality water for the city.

\subsection{Major Challenges}

\section{Technical Challenges}

The original goal of sponge city construction was defined as the introduction of runoff-volume-focused LID techniques to retain 60-90\% runoff onsite [17,29]. One year later (in 2016), the goals were expanded to a full array of urban sustainability goals by adding restoration of ecosystem, improving deteriorated urban water bodies, reducing urban heat island impacts, and building smart urban water cycles [17,29]. The concept and practice of LID techniques were introduced into China more than a decade ago [45]. Recent research has been carried out on sustainable urban stormwater management, but the research foundation for sponge city construction on such a large scale is rather limited. The rapid implementation of sponge city measures with such ambitious goals is largely based on very little domestic research [46,47]. A sponge city is an integrated approach that involves a broad range of concepts such as multi-scale conservation and water system management, multi-functional ecological systems, urban hydrology and runoff control frameworks, and impacts of urbanization and human activities on the natural environment. Lacking a sound research foundation can unnecessarily restrict the potentially positive impacts of this new urban water cycle management approach. To implement sponge cities successfully, an appropriate definition of goals and adequate research to understand this new approach (along with sufficient knowledge) is very crucial [31,47].

\section{Conclusions}

A framework of objectives and indexes has been proposed in this study to providing guidelines to transform the Changzhou city into a sponge city. The application of the framework in this study indicated that: 1 . the water surface ratio in the central area of Changzhou city is projected to exceed $4.7 \%$ by 2020 and $5 \%$ by 2030, 2. the effective soil cover thickness of underground spaces of sponge green lands should not be less than 1.5 meters, and the thickness of soil covering in the upper part of the underground space should not be less than $1.8 \mathrm{~m}$ ideally, 3 . the ratio of sponge green spaces in each control unit consists of different land types, therefore this indicator needs to be delineated according to control units, 4 . water quality compliance rate should increase to $85 \%$ in the central urban districts of Changzhou city with separated systems, reaching $100 \%$ by 2030.5 . the river and lake ecological bank fraction in the central urban districts of Changzhou city should exceed $50 \%$ by 2020, and $70 \%$ by 2030 . 6. rainwater resource utilization ratio should not be less than $1.5 \%$ by 2020 , and $2 \%$ by 2030 . Sponge city can be described as a vision that people, the city and water coexist harmoniously in the future. It is a new solution to the problems produced in the city development process in municipalities of the Yangtze River Delta and is the best way for cities to sustainably develop. 
Author Contributions: Z.L., T.W., J.W. and R.P.S. conceived and designed the experiments; R.P.S., M.D., A.J.K. performed the experiments and analyzed the data; and R.P.S. wrote the paper.

Funding: This study was funded by the National Key Technologies Research \& Development Program, China (No. 2015BAL02B05).

Acknowledgments: Authors would like to thank Willium Hunt, North Carolina State University for his valuable suggestions.

Conflicts of Interest: The authors declare no conflict of interest.

\section{References}

1. Chocat, B.; Krebs, P.; Marsalek, J.; Rauch, W.; Schilling, W. Urban drainage redefined; from stormwater removal to integrated management. Water Sci. Technol. 2001, 43, 61-68. [PubMed]

2. Fltcher, T.D.; Andrieu, H.; Hamel, P. Understanding management and modelling of urban hydrology and its consequences for receiving waters; a state of the art. Adv. Water Resour. 2013, 51, 261-279. [CrossRef]

3. Boquet, Y. Metro Manila's challenges: Flooding, housing and mobility. In Urban Development Challenges, Risks and Resilience in Asian Mega Cities; Springer: Tokyo, Japan, 2014; pp. 447-468.

4. Jiang, Y.; Zevenbergen, C.; Ma, Y. Urban pluvial flooding and stormwater management: A contemporary review of China's challenges and "sponge cities" strategy. Environ. Sci. Policy 2018, 80, 132-143. [CrossRef]

5. Wang, C.; Wang, Y.; Geng, Y.; Wang, R.; Zhang, J. Measuring regional sustainability with an integrated social-economic-natural approach: A case study of the Yellow River Delta region of China. J. Clean. Prod. 2016, 114, 189-198. [CrossRef]

6. Shao, W.; Zhang, H.; Liu, J.; Yang, G.; Chen, X.; Yang, Z.; Huang, H. Data integration and its application in the sponge city construction of China. Proc. Engi. 2016, 154, 779-786. [CrossRef]

7. Feng, H.; Cheng, G.; Liang, J.; Gao, F. Inspiration of rainwater utilization plan in Denmark for the construction of sponge city in China. DEStech Trans. Environ. Energy Earth Sci. 2017, 131-134. [CrossRef]

8. Rui, Y.H.; Fu, D.F.; Do Minh, H.; Radhakrishnan, M.; Zevenbergen, C.; Pathirana, A. Urban surface water quality, flood water quality and human health impacts in Chinese cities: What do we know? Water 2018, 10, 240. [CrossRef]

9. Fratini, C.; Geldof, G.D.; Kluck, J.; Mikkelsen, P.S. Three points approach (3PA) for urban flood risk management: A tool to support climate change adaptation through transdisciplinarity and multifunctionality. Urban Water J. 2012, 9, 317-331. [CrossRef]

10. Marsalek, J.; Chocat, B. International report: Stormwater management. Water Sci. Technol. 2002, 46, 1-17. [PubMed]

11. Wong, T.H.F. Water sensitive urban design-A journey thus far. Aust. J. Water Resour. 2007, 110, $213-222$. [CrossRef]

12. Ashley, R.; Lundy, L.; Ward, S.; Shaffer, P.P.; Walker, L.; Morgan, C.; Saul, A.; Wong, T.; Moore, S. Water sensitive urban design: Opportunities for the UK. Proc. ICE-Munic. Eng. 2013, 166, 65-76. [CrossRef]

13. Zevenbergen, C.; Herk, S.V.; Rijke, J. Future proofing flood risk management: Setting the stage for an integrative, synergistic and adaptive approach. Public Works Manag. Policy 2016, 22, 49-54. [CrossRef]

14. Wei, D.; Urich, C.; Liu, S.; Gu, S. Application of CityDrain3 in flood simulation of sponge polders: A case study of Kunshan, China. Water 2018, 10, 507. [CrossRef]

15. Salinas-Rodriguez, C.; Gersonius, B.; Zevenbergen, C.; Serrano, D.; Ashley, R. A semi risk-based approach for managing urban drainage systems under extreme rainfall. Water 2018, 10, 384. [CrossRef]

16. Fenner, R. Spatial evaluation of multiple benefits to encourage multi-functional design of sustainable drainage in blue-green cities. Water 2017, 9, 953. [CrossRef]

17. Ministry of Housing and Urban-Rural Development, China (MHURD-China). Technical Guide for Sponge Cities-Water System Construction with Low Impact Development Techniques. Available online: http://www.mohurd.gov.cn/zcfg/jsbwj_0/jsbwjcsjs/201411/W020141102041225.pdf (accessed on 22 October 2016).

18. United States Environmental Protection Agency (US EPA). Low-Impact Development Design Strategies: An Integrated Design Approach; EPA 841-B-00003; US EPA: Washington, DC, USA, 1999.

19. Benedict, M.; McMahon, E. Green infrastructure: Smart conservation for the 21st century. Renew. Resour. J. 2002, 20, 12-17. 
20. British Columbia Ministry of Environment (BCME). Stormwater Planning: A Guidebook for British Columbia. Available online: http:/ / www.env.gov.bc.ca/epd/mun-waste/waste-liquid/stormwater/ (accessed on 4 September 2016).

21. Olewiler, N. The Value of Natural Capital in Settled Areas of Canada; Ducks Unlimited Canada and The Nature Conservancy of Canada: Toronto, ON, Canada, 2004.

22. Alexander, D.; Tomalty, R. Smart growth and sustainable development: Challenges, solutions and policy directions. Local Environ. 2002, 7, 397-409. [CrossRef]

23. STU. La Ma^trise du des eaux Pluviales: Quelques Solutions pour L'ame'Lioration du cadre de vie (The Management of Urban Stormwater: Solutions for Environmental Improvement); Ministe're de l'Urbanisme et du Logement, Direction de l'Urbanisme et des Paysages, Service Technique de l’Urbanisme: Paris, France, 1982. (In French).

24. Lehmann, S. UNESCO chair in sustainable urban development. In The Principles of Green Urbanism; Earth Scan: London, UK, 2010.

25. Beatly, T. Green Urbanism: Learning from European Cities; Island Press: Washington, DC, USA, 1999.

26. Sharma, A.K.; Pezzaniti, D.; Myers, B.; Cook, S.; Tjandraatmadja, G.; Chacko, P.; Chavoshi, S.; Kemp, D.; Leonard, R.; Koth, B. Water sensitive urban design: An investigation of current systems, implementation drivers, community perceptions and potential to supplement urban water services. Water 2016, 8, 272. [CrossRef]

27. Jenkins, S. Towards Regenerative Development. Available online: www.planning.nz (accessed on 10 September 2016).

28. Jia, H.; Wang, Z.; Zhen, X.; Clar, M.; Yu, S.L. China's sponge city construction: A discussion on technical approaches. Front. Environ. Sci. Eng. 2017, 11, 18. [CrossRef]

29. General Office of the State Council (GOSC). Guideline to Promote Building Sponge Cities. Available online: http:/ / www.gov.cn/zhengce/content/2015-10/16/content_10228.html (accessed on 16 October 2015).

30. Li, H.; Ding, L.; Ren, M.; Li, C.; Wang, H. Sponge city construction in China: A survey of the challenges and opportunities. Water. 2017, 9, 594. [CrossRef]

31. Marshall, W.E. An evaluation of livability in creating transit-enriched communities for improved regional benefits. Res. Transp. Bus. Manag. 2013, 7, 54-68. [CrossRef]

32. Zheng, Y.; Yong, X. Unconventional water resources. Water Purif. Technol. 2003, 6, 38-40. (In Chinese)

33. Zhou, Q.; Mikkelsen, P.S.; Halsnaes, K.; Arnbjerg-Nielsen, K. Framework for economic pluvial flood risk assessment considering climate change effects and adaptation benefits. J. Hydrol. 2012, 414, 539-549. [CrossRef]

34. Foster, S.B.; Allen, D.M. Ground water-Surface water interactions in a mountain-to-coast watershed: Effects of climate change and human stressors. Adv. Meteorol. 2015, 22. [CrossRef]

35. Li, C. Ecohydrology and good urban design for urban storm water-logging in Beijing, China. Ecohydrol. Hydrobiol. 2012, 12, 287-300. [CrossRef]

36. Kang, N.; Kim, S.; Kim, Y.; Noh, H.; Hong, S.J.; Kim, H.S. Urban drainage system improvement for climate change adaptation. Water 2016, 8, 268. [CrossRef]

37. Torgersen, G.; Bjerkholt, J.T.; Lindholm, O.G. Addressing flooding and SuDS when improving drainage and sewerage systems-A comparative study of selected Scandinavian cities. Water 2014, 6, 839-857. [CrossRef]

38. United States Environmental Protection Agency (US EPA). Combined Sewer Overflow Control Manual; US EPA: Washington, DC, USA, 1984.

39. Wu, J. Analysis on the current situation and development problem of China's sponge city construction-Case study on Ningbo Yaojiang-Cicheng pilot area. Saudi J. Hum. Soc. Sci. 2017, 2, 572-577.

40. Xiao, L.; Yangn, X.; Cai, H. Responses of sediment yield to vegetation cover changes in the Poyang Lake drainage area, China. Water 2016, 8, 114. [CrossRef]

41. Xin, R.; Weizhen, T. Application of capture ratio of total annual runoff volume in sponge city. China Water Wastewater 2015, 31, 105-109. (In Chinese)

42. Wu, Y.; Dai, H.; Wu, J. Comparative study on influences of bank slope ecological revetments on water quality purification pretreating low-polluted waters. Water 2017, 9, 636. [CrossRef]

43. Shishegar, N. The impact of green areas on mitigating urban heat island effect: A review. J. Environ. Sustain. 2014, 9, 119-130. [CrossRef] 
44. McDonald, R.I.; Green, P.; Balk, D.; Fekete, B.M.; Revenga, C.; Todd, M.; Montgomery, M. Urban growth, climate change, and freshwater availability. Proc. Natl. Acad. Sci. USA 2011, 108, 6312-6317. [CrossRef] [PubMed]

45. Ries, F.; Schmidt, S.; Sauter, M.; Lange, J. Controls on runoff generation along a steep climatic gradient in the Eastern Mediterranean. J. Hydrol. Reg. Stud. 2017, 9, 18-33. [CrossRef]

46. Wu, C.; Li, Z. The current situation and future trend of urban rain water harvesting. Water Wastewater Eng. 2002, 28, 12-14.

47. Wang, H.; Cheng, X.; Li, C. Quantitative analysis of storm water management strategies in the process of watershed urbanization. J. Hydraul. Eng. 2015, 46, 19-27.

2018 by the authors. Licensee MDPI, Basel, Switzerland. This article is an open access article distributed under the terms and conditions of the Creative Commons Attribution (CC BY) license (http://creativecommons.org/licenses/by/4.0/). 